\title{
The association of state per capita income and military service deaths in the Vietnam and Iraq wars Charles Maynard
}

Address: Department of Health Services, University of Washington, Seattle, Washington, USA

Email: Charles Maynard - cmaynard@u.washington.edu

Published: 6 January 2009

Population Health Metrics 2009, 7:1 doi:10.1 I86/1478-7954-7-1
Received: 26 August 2008

Accepted: 6 January 2009

This article is available from: http://www.pophealthmetrics.com/content/7/I/I

(c) 2009 Maynard; licensee BioMed Central Ltd.

This is an Open Access article distributed under the terms of the Creative Commons Attribution License (http://creativecommons.org/licenses/by/2.0), which permits unrestricted use, distribution, and reproduction in any medium, provided the original work is properly cited.

\begin{abstract}
Background: In the United States, social burdens including war casualties are often distributed unequally across groups of individuals, communities, and states. The purpose of this report was to examine the association between war deaths and per capita income in the 50 states and District of Columbia during the Vietnam and Iraq wars.

Methods: The numbers of deaths by the home state of record for each conflict were obtained from Department of Defense records on the Internet as were key variables including age at death, gender, race, branch of service, rank, circumstances of death, home state of record and the ratio of wounded to dead. In addition, we obtained state per capita income and state population for the relevant times.

Results: Characteristics of decedents in the 2 conflicts were very similar with young, white enlisted men accounting for the majority of deaths. However, in the Iraq war, women accounted for a $2.4 \%$ of casualties. Also of note was the higher ratio of wounded to dead in Iraq. At the level of the state, the correlation between the ratio of deaths per 100,000 and per capita income was $0.5 \mathrm{I}(\mathrm{p}<0.000 \mathrm{I})$ for Vietnam and -0.52 for Iraq $(\mathrm{p}<0.000 \mathrm{I})$. In both eras, states with lower per capita income tended to have higher ratios of deaths per population.

Conclusion: For military service members serving in the Vietnam and Iraq conflicts, there were many more women who died in the latter war. Whether war deaths resulted in lower per capita income cannot be determined from these cross sectional data; we simply note a strong association between per capita income and war casualty rates for both wars.
\end{abstract}

\section{Background}

In the United States, social burdens including war casualties are often distributed unequally across groups of individuals, communities, and states. In both Vietnam and Iraq the majority of deaths occurred in white enlisted men who served in the US Army or Marine Corps in hostile situations [1-4]. Less is known about the association between war casualties and income of states. The purpose of this report was to examine the association between war deaths and per capita income in the 50 states and District of Columbia during the Vietnam and Iraq wars. A secondary objective was to compare the characteristics of individuals who died in the 2 conflicts.

\section{Methods}

The numbers of deaths by the home state of record for each conflict were obtained from the World Wide Web $[2,4]$ as were key variables including age at death, gender, 
race, branch of service, rank (enlisted versus officer or warrant officer), circumstances of death (hostile versus nonhostile), and the home state of record. Hostile deaths refer to those personnel who were killed in action, died of wounds, were missing in action, or died in captivity. Tabular counts of decedents (e.g., number of deaths by age) for the Vietnam war were obtained from the National Archives of the United States, which in turn received archival records from the Department of Defense [2]. Detailed individual level characteristics of decedents in the Iraq war were obtained from publicly available files provided by the Defense Manpower Data Center [4]. Death information for the Iraq war is changing as the war is ongoing. The ratio of wounded to dead was calculated for the conflicts in Vietnam and Iraq [5,6]. Race was defined differently in the 2 periods; in order to compare racial characteristics during the 2 time periods, race was categorized as white or non-white.

The ratio of state deaths to state population was calculated as the number of deaths per state of record to state population in either 1970 or 2000 . State population figures for the years 1970 and 2000 were obtained from the Pennsylvania State Data Center [7]. Per capita income in 1999 dollars for the years 1969 and 1999 (the latest year for which information was available) was obtained from the US Census [8]. The association between per capita income and the ratio of the number of deaths to state population was examined with the Spearman rank correlation coefficient for the Vietnam and Iraq wars separately.

\section{Results}

The numbers of deaths in Vietnam exceeded those in Iraq by more than 10 times as deaths in Vietnam spanned the years 1956 through 1998, whereas those for the ongoing Iraq war covered the years 2003 to July 2008. Vietnam deaths after 1975 were for individuals whose status changed from missing to deceased. The characteristics of casualties in Vietnam and Iraq were similar, with the exception that the number of women increased significantly in Iraq (table 1). In Vietnam, there were only 8

Table I: Characteristics of casualties in the Vietnam and Iraq wars

\begin{tabular}{lcc}
\hline Characteristic & $\begin{array}{c}\text { Vietnam } \\
(\mathbf{n}=\mathbf{5 8 , 1 9 3 )}\end{array}$ & $\begin{array}{c}\text { Iraq } \\
(\mathbf{n}=\mathbf{4 1 0 6})\end{array}$ \\
\hline Age in years (median) & 21 & 24 \\
Men & $100 \%$ & $98 \%$ \\
White & $86 \%$ & $75 \%$ \\
United States Army & $66 \%$ & $72 \%$ \\
United States Marine Corps & $25 \%$ & $24 \%$ \\
Enlisted personnel & $86 \%$ & $91 \%$ \\
Hostile death & $81 \%$ & $81 \%$ \\
Ratio of wounded to dead & $2.6 / 1$ & $7.5 / 1$ \\
\hline
\end{tabular}

recorded deaths in women, whereas in the Iraq there were 92 women who died. Another difference was that the ratio of wounded to dead was much higher in Iraq.

As seen in the table 2, the average per capita income in 1969 in 1999 dollars was $\$ 11.5$ thousand compared to $\$ 20.9$ thousand in 1999 . The ratio of deaths per 100,000 was 29.8 for Vietnam and 1.6 for Iraq. The correlation between the ratio of deaths per 100,000 and per capita income was $-0.51(\mathrm{p}<0.0001)$ for Vietnam and -0.52 for Iraq $(p<0.0001)$. In both eras, states with lower per capita income tended to have higher ratios of deaths per population (figures 1 and 2).

\section{Discussion}

Much has been said about similarities and differences between the conflicts in Vietnam and Iraq. The former was fought by draftees and volunteers, whereas the current conflict includes only volunteers, as at this time there is no military draft in the United States. One striking difference was the numbers of deaths in Vietnam far exceeded those in the ongoing Iraq war. On the other hand, characteristics of decedents in the 2 conflicts were very similar with young, white enlisted men accounting for the majority of deaths. However, in the Iraq war, women accounted for a higher proportion of casualties. Also of note was the difference in the ratio of wounded to dead in the 2 conflicts. This may be an indication of improved medical care in the Iraq war, as personnel with severe injuries are surviving wounds that in previous wars were lethal [9].

It was also the case that states with fewer resources as measured by per capita income experienced higher casualty rates in both conflicts. The magnitude of the association was relatively strong and remarkably similar in both eras. For states and the armed forces, this meant the loss of young men and women; the loss of young women is particularly applicable to the Iraq conflict, where women currently account for $2.4 \%$ of deaths $[2,4]$.

A major limitation of the study was that the state population was used as the denominator. A better denominator would have been the number of combatants from each state, as it is likely that individuals from poorer states were more likely to join the military than were those from wealthier states. Unfortunately, it was not possible to obtain counts of the number of combatants by state.

While there could have been selection bias in that men and women from poorer states were more likely to join the military, this does not change the fact that poorer states had higher casualty rates. This study was based on publicly available data over which the author had little control; information was used as provided. For example, 1999 was latest year for which state per capita income was 
Table 2: Ratio of deaths to population and per capita income by state during the Vietnam and Iraq wars

\begin{tabular}{|c|c|c|c|c|}
\hline State & $\begin{array}{c}\text { \# deaths } / 100,000 \\
\text { (Vietnam) }\end{array}$ & $\begin{array}{c}\text { \# deaths/I00,000 } \\
\text { (Iraq) }\end{array}$ & $\begin{array}{c}\text { Per capita income } \\
\text { (1969) }\end{array}$ & $\begin{array}{c}\text { Per capita income } \\
\text { (1999) }\end{array}$ \\
\hline Alabama & 35.05 & 1.51 & 9,026 & 18,189 \\
\hline Alaska & 18.81 & 2.71 & $|4,5| \mid$ & 22,660 \\
\hline Arizona & 35.10 & 1.87 & 11,442 & 20,275 \\
\hline Arkansas & 30.58 & 2.21 & 8,345 & 16,904 \\
\hline California & 27.91 & 1.31 & 14,079 & 22,711 \\
\hline Colorado & 28.05 & 1.40 & 12,100 & 24,049 \\
\hline Connecticut & 20.15 & 0.82 & 15,135 & 28,766 \\
\hline Delaware & 31.97 & 0.87 & 12,719 & 23,305 \\
\hline District of Columbia & 22.26 & 1.79 & 14,967 & 28,659 \\
\hline Florida & 28.74 & 1.09 & 11,913 & 21,557 \\
\hline Georgia & 34.48 & 1.55 & 10,285 & 21,154 \\
\hline Hawaii & 35.84 & 1.73 & 13,140 & 21,525 \\
\hline Idaho & 30.43 & 2.32 & 10,300 & $|7,84|$ \\
\hline Illinois & 26.41 & 1.17 & 13,615 & 23,104 \\
\hline Indiana & 29.49 & 1.48 & 11,960 & 20,397 \\
\hline lowa & 30.19 & 1.64 & 11,235 & 19,674 \\
\hline Kansas & 27.88 & 1.60 & 11,410 & 20,506 \\
\hline Kentucky & 32.75 & 1.51 & 9,447 & 18,093 \\
\hline Louisiana & 24.20 & 1.79 & 9,077 & 16,912 \\
\hline Maine & 34.51 & 1.96 & 9,926 & 19,533 \\
\hline Maryland & 25.84 & 1.27 & 13,682 & 25,614 \\
\hline Massachusetts & 23.26 & 1.06 & 13,276 & 25,952 \\
\hline Michigan & 29.88 & 1.49 & 13,078 & 22,168 \\
\hline Minnesota & 28.17 & 1.22 & 11,835 & 23,198 \\
\hline Mississippi & 28.73 & 1.79 & 7,499 & 15,853 \\
\hline Missouri & 30.21 & 1.43 & 11,500 & 19,936 \\
\hline Montana & 38.62 & 2.66 & 10,503 & $17,15 \mid$ \\
\hline Nebraska & 26.60 & 2.51 & 10,896 & 19,613 \\
\hline Nevada & 30.88 & 1.75 & 13,845 & 21,989 \\
\hline New Hampshire & 30.76 & 1.78 & 11,629 & 23,844 \\
\hline New Jersey & 20.69 & 0.83 & 14,313 & 27,006 \\
\hline New Mexico & 39.23 & 1.98 & 9,494 & $|7,26|$ \\
\hline New York & 22.59 & 0.94 & 14,056 & 23,389 \\
\hline North Carolina & 31.65 & 1.22 & 9,638 & 20,307 \\
\hline North Dakota & 32.04 & 2.18 & 9,618 & 17,769 \\
\hline Ohio & 29.05 & 1.51 & 12,462 & 21,003 \\
\hline Oklahoma & 38.61 & 1.88 & 10,495 & 17,646 \\
\hline Oregon & 33.89 & 2.02 & 12,264 & 20,940 \\
\hline Pennsylvania & 26.64 & 1.52 & 11,944 & 20,880 \\
\hline Rhode Island & 21.79 & 0.95 & 12,158 & 21,688 \\
\hline South Carolina & 34.58 & 1.20 & 8,972 & 18,795 \\
\hline South Dakota & 28.98 & 2.38 & 9,299 & 17,562 \\
\hline Tennessee & 32.88 & 1.46 & 9,599 & 19,393 \\
\hline Texas & 30.49 & 1.87 & 10,877 & 19,617 \\
\hline Utah & 34.56 & 0.99 & 10,507 & 18,185 \\
\hline Vermont & 22.47 & 3.45 & 10,799 & 20,625 \\
\hline Virginia & 28.04 & 1.68 & $|1,67|$ & 23,975 \\
\hline Washington & 30.76 & $\mathrm{I} .4 \mathrm{I}$ & 13,078 & 22,973 \\
\hline West Virginia & 41.97 & 1.22 & 9,089 & 16,477 \\
\hline Wisconsin & 26.28 & 1.66 & 11,812 & $21,27 \mid$ \\
\hline Wyoming & 36.14 & 2.43 & 11,278 & 19,134 \\
\hline
\end{tabular}




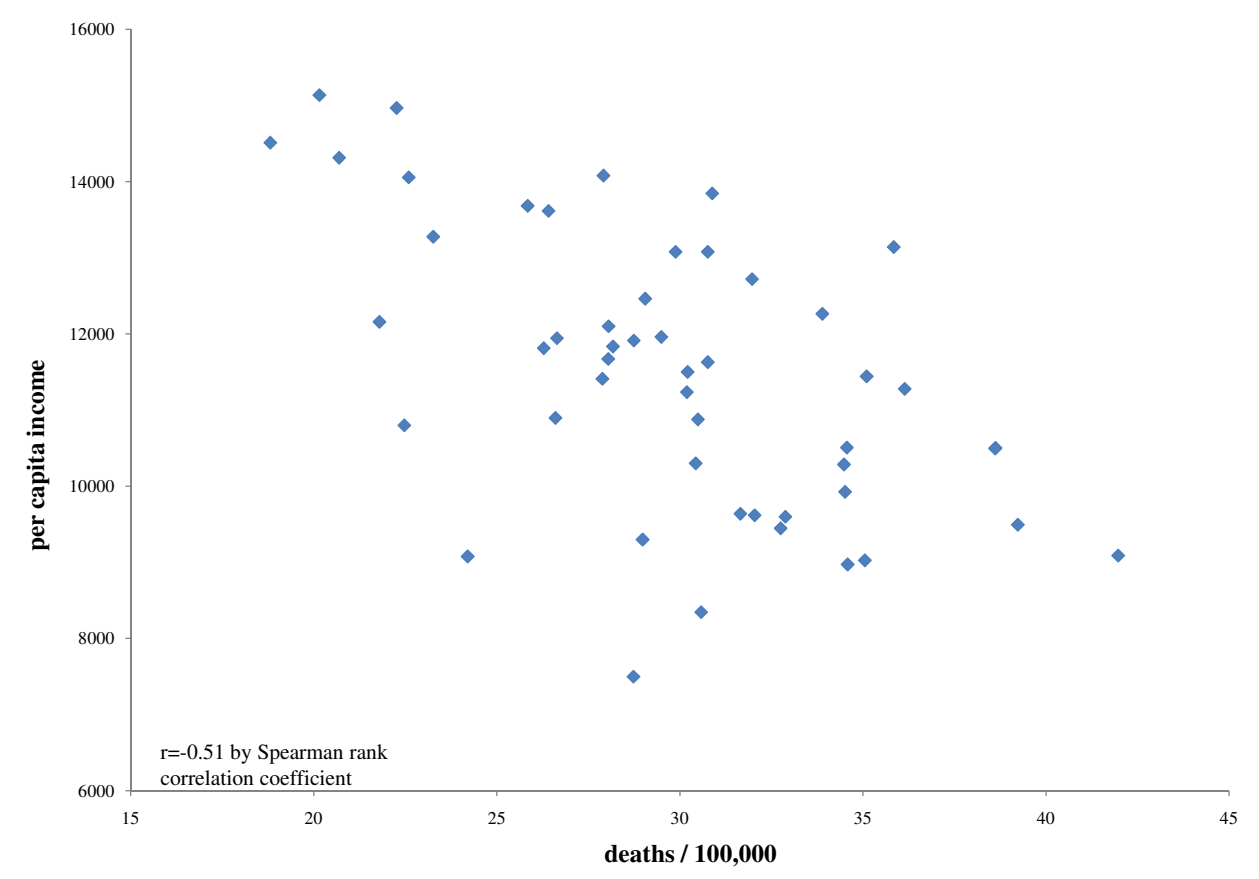

Figure I

Combat casualties and state per capita income during the Vietnam war.

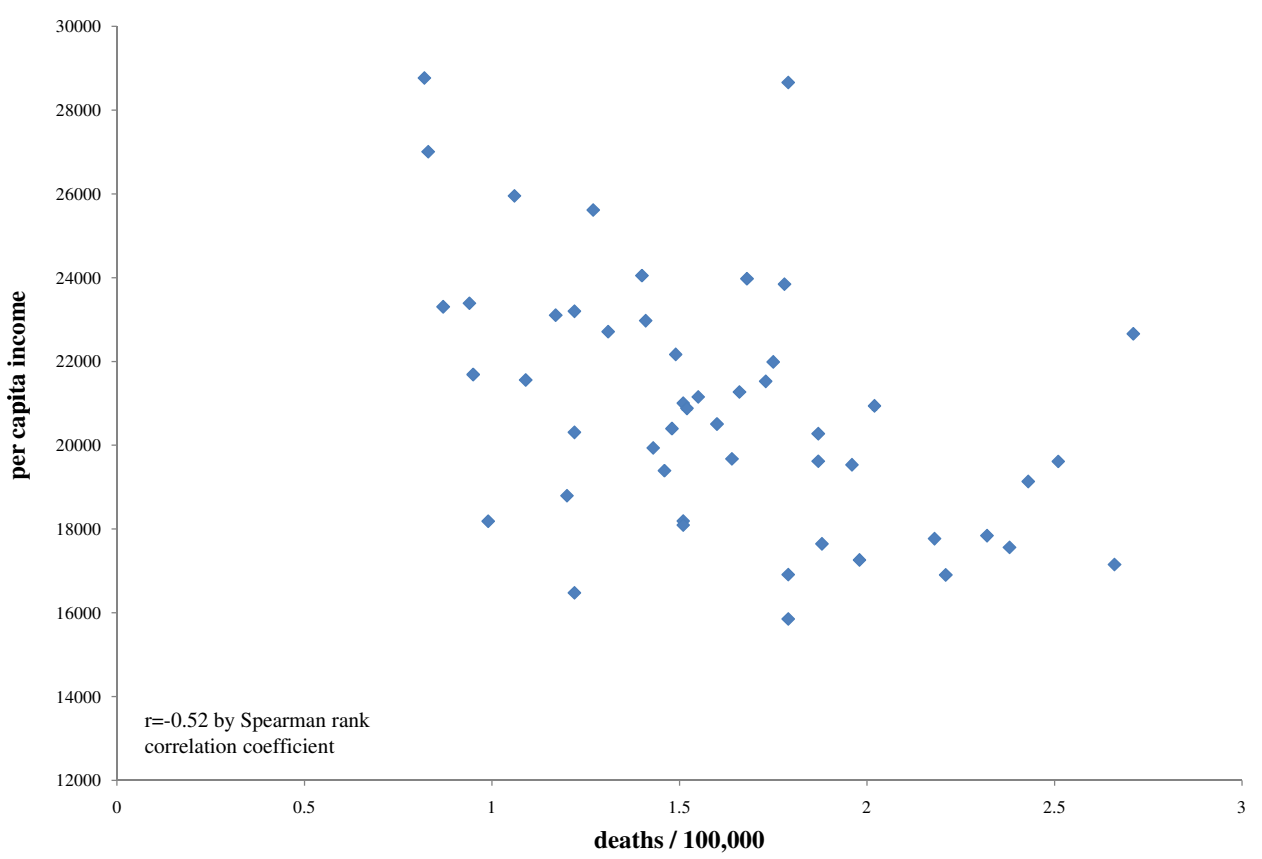

Figure 2

Combat casualties and state per capita income during the Iraq war. 
reported; this was 4 years prior to the start of the Iraq War. Furthermore, the information regarding deceased combatant's characteristics was taken "as is." The author was not able to assess the accuracy of the information; this applies particularly to the Vietnam war which started over 45 years ago.

\section{Conclusion}

In the Vietnam and Iraq conflicts, the burden of war casualties was shouldered primarily by young enlisted men, but as seen in Iraq, young women are beginning to share this burden. Less appreciated is the fact that populations may be affected by war casualties in military personnel. Whether war deaths cause states to have lower income cannot be determined from these cross sectional data; we simply note a strong association between per capita income and war casualty rates in the 2 conflicts.

\section{Competing interests}

The author declares that they have no competing interests.

\section{Authors' contributions}

Charles Maynard is the sole author of this study and was responsible for study design, conception, data analysis and interpretation. He also drafted the manuscript, critically revised it for important intellectual content, and approved the final version of manuscript.

\section{Acknowledgements}

This study was not supported by any funding agency.

\section{References}

I. Buzzell E, Preston SH: Mortality of American troops in the Iraq War. Pop Develop Review 2007, 33:555-566.

2. Statistical information about casualties of the Vietnam War [http://www.archives.gov/research/vietnam-war/casualty-statis tics.html]. Washington, DC: The US National Archives and Records Administration accessed July 8, 2008

3. Gifford B: Combat casualties and race: What can we learn from the 2003-2004 Iraq conflict? Armed Forces and Society 2005, $3 \mathrm{I}: 20 \mathrm{I}-225$.

4. Operation Iraqi Freedom names, alphabetical order (as of July 5, 2008) [http://siadapp.dmdc.osd.mil/personnel/CASUALTYI castop.htm]. Washington, DC: Department of Defense accessed July 8, 2008

5. Vietnam Conflict-casualty summary (as of May 16, 2008) [http://siadapp.dmdc.osd.mil/personnel/CASUALTY/vietnam.pdf]

Washington, DC: Department of Defense accessed August 23, 2008

6. Operation Iraqi Freedom military wounded in action since May I, 2003 (as of August 2, 2008) [http://siadapp.dmdc.osd.mil/ personnel/CASUALTY/OIF-Wounded-After.pdf]. Washington, DC: Department of Defense accessed August 23, 2008

7. Population by state: 1980, 1990, and $2000 \quad 1970$ [http:pasdc.hbg.psu.edu/pasdc/PA Stats/profiles tables and charts/ penn sylvania/pop other/04XTI-0I.html]. Middletown, Pennsylvania: Pennsylvania State Data Center accessed July 10, 2008

8. Per capita income by state: 1969, 1879, 1989, and 19991959 [http://www.census.gov/hhes/www/income/histinc/state/state3.html] Washington, DC: US Census Bureau accessed July 9, 2008

9. Gawande A: Casualties of war - military care for the wounded from Iraq and Afghanistan. N Engl J Med 2004, 35 I:247 I-2475.

\section{Publish with Bio Med Central and every} scientist can read your work free of charge

"BioMed Central will be the most significant development for disseminating the results of biomedical research in our lifetime. "

Sir Paul Nurse, Cancer Research UK

Your research papers will be:

- available free of charge to the entire biomedical community

- peer reviewed and published immediately upon acceptance

- cited in PubMed and archived on PubMed Central

- yours - you keep the copyright

Submit your manuscript here:

http://www.biomedcentral.com/info/publishing_adv.asp
BioMedcentral 